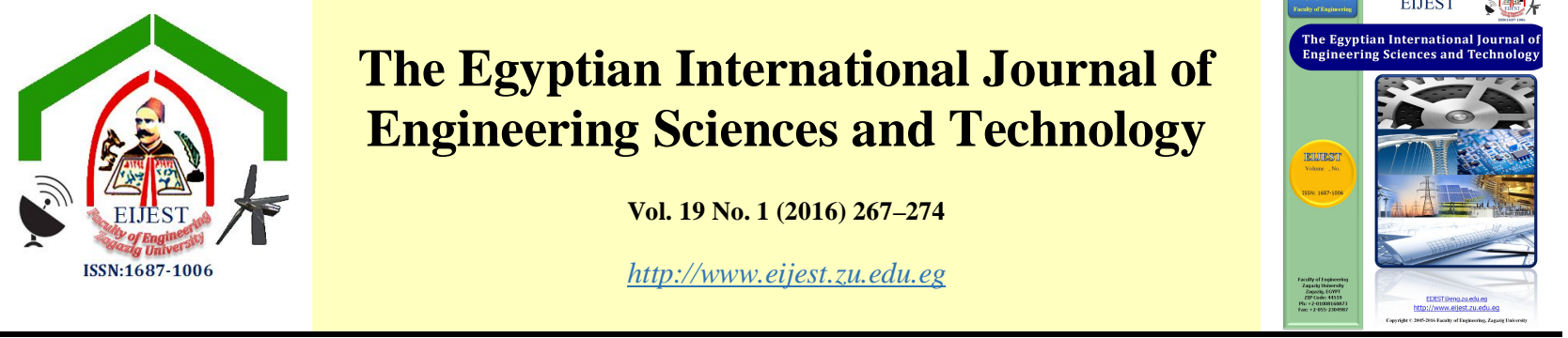

\title{
Soft Clay Treatment Using Portland Cement and Hydrated Lime
}

\author{
Tarek N. Salem ${ }^{\mathrm{a}}$, Mahmoud S. El-Kady ${ }^{\mathrm{b}}$, Ahmed M. Abd-Elbaset ${ }^{\mathrm{a}, \mathrm{b},{ }^{*}}$ \\ Structural Eng. Dept., Faculty of Eng., Zagazig University, Egypt.
}

\begin{abstract}
A R T I C L E I NFO
Article history:

Received 00 March 2013

Received in revised form:

Accepted 00 June 2014

Available online:

Keywords:
$1^{\text {st }}$ Soft Clay
$2^{\text {nd }}$ Soil Stabilization
$3^{\text {st }}$ Hydrated Lime
$4^{\text {nd }}$ Portland Cement
$5^{\text {st }}$ Unconfined Compression
Strength
$6^{\text {nd }}$ Small Scale Model

A B S T R A C T

Soft soils often cause difficulties in construction operations with their low strength, low strength, and high compressibility. However, the engineering properties of these soils can be enhanced by soil stabilization. This research is carried out to study the effects of using hydrated lime and Portland cement for stabilization of soft clay soil collected from the cleaning of Mowais canal bed in Zagazig, Egypt. Two types of experimental testing are performed on the natural and stabilized soils. Unconfined compression strength tests are conducted on treated and untreated soft clay samples. In addition, model footing tests are also conducted on the untreated and treated soft soils.

Unconfined compression test results showed that mixing hydrated lime and Portland cement with soft clay soils are effective in increasing the treated soft soil strength and reducing its compressibility. Soils treated with high dosage of cement (from $7 \%$ to $10 \%$ ) showed lower effectiveness of lime. However, for low dosage cement $(4 \%)$, the lime effectiveness is significant. Curing time has a noticeable impact on the strength of the cement-treated samples and cement-lime mixture treated samples. Model tank tests are performed to study the effect of treated soft clay with $4 \%$ cement $+4 \%$ lime on the settlement of $(10 * 10 \mathrm{~cm})$ square model footing. Results showed that the measured settlements in treated soils are remarkably lower than the untreated ones especially when increasing the depth and extension of treated zone under footing.
\end{abstract}

\section{INTRODUCTION}

Large zones of Northern Egypt are covered by deep layers of soft clay which hinders the development in these zones. The soft clay in these zones has very low shear strength along with sustaining large settlements when loaded. Thus, the purpose of this research is not to induce dramatic increase in the soil load bearing capacity and large reductions in settlements, but rather to attain the minimum strength values that make the development of these zones possible for human activities. An allowable bearing capacity as low as $30 \mathrm{kPa}$ will allow for safe construction of highways and low rise residential buildings, which is the main target of this paper.

Soft soils are characterized by their low strength and high compressibility. Usually, due to sedimentary process on different environments, both physical and engineering properties show a significant variation in clay formation. Furthermore, these soils exhibit high compressibility, reduced strength, low permeability and compactness, and consequently low quality for construction, (Nordin, 2010). 
Rafalko (2006) presented a case study involving stabilization of soft clay soils (initially with California Bearing Ratio, $\mathrm{CBR}=2.0 \%$ ) to support C17 and C-130 aircraft traffic. The research target was to increase the CBR to $80 \%$ within very short period of time to be able to support the required aircraft traffic. It was found that the required design strengths for many loading conditions were achieved by treating clay with $2 \%-4 \%$ pelletized quicklime for the underlying sub base layer, and treating clay with $2 \%$ $4 \%$ pelletized quicklime, $1 \%$ RSC15 fibers, and $11 \%$ Type III (ultra fine cement) for the top base layer.

Geiman (2005) indicated that lime and Portland cement were far more effective than the liquid stabilizers in increasing the strength of Virginia soils. Portland cement treatment produced the highest strength, associated with higher cost.

Dhakal (2009) found that lime stabilization is less effective in silty soils. Low to medium plastic soil (PI < 30\%) performed better when treated with cement only, whereas lime and/or lime plus cement were required to stabilize highly plastic soils.

Portelinha et al. (2012) indicated that addition of $2 \%$ and $3 \%$ of lime or cement was enough to change the soil consistency and strength. The soil modification promoted increase in strength and initial tangent modulus, mainly after 28 days of curing, where cement was more efficient. The highest alterations in strength occurred at $2 \%$ and $3 \%$ of lime and cement, although addition of $1 \%$ was sufficient to provide about $50 \%$ increase in the unconfined compressive strength when compared with the untreated soil.

\section{EXPERIMENTAL WORK \\ 2.1 Soil Specimens}

The soft soil samples are obtained from cleaning the bed of Mowais canal, which is tributary of the Nile River passing through Zagazig city. Samples are placed in secure closed moulds and then transported to the laboratory while preserving their consistency and natural water content. Wide range of index tests is conducted on the soft clay specimens. All the tests are performed according to the appropriate ASTM standards for the purpose of classification and quantification of their properties. Index test results showed that the natural water content of soil is about $43 \%$, and its liquid limit $=$ $48.8 \%$, plastic limit $=30 \%$, and plasticity index $=$ $18.8 \%$. It was also found that the classification of soil according to USCS is MI, silt of medium plasticity.

\subsection{Stabilizers}

Soil stabilization is the process of improving the physical and engineering properties of a soil to obtain some predetermined targets. Using chemical additives is an important procedure among different methods of soil improvement, in order to increase the strength parameters and load bearing capacity of soft soils. In this research, Portland cement and/or hydrated lime are chosen for soil treatment. Hydrated lime is used instead of quick lime because of its high hydrophilic ability which endangers their users for causing burns and strong reaction when added to saturated soft clay. In addition most previous researches used hydrated lime in the treatment (Zukri, 2013; Yunus et al., 2012; Muhmed and Wanatowski, 2013; Ismaiel, 2006; Dhakal, 2009; Portelinha, 2012; Geiman, 2005).

\subsection{Unconfined Compression Strength Tests}

A total of 96 unconfined compression tests are conducted on lime/cement, and cement treated specimens where the main variables are percentage of stabilizer and time of curing, as presented in Table (1). The specific stabilizer quantity is prepared then mixed with the natural soft clay specimens according to ASTM D1633.

\subsubsection{Soil Sample Preparation}

For this study, the percentage of stabilizer to be used is predefined in terms of the calculated dry weight of soil to be treated. The stabilizer is sprinkled over the natural soil, and mixing continued till the mixture achieves uniform consistency and color. The prepared stabilized soil samples are then cast into specially prepared sample molds, as shown in Photo (1).

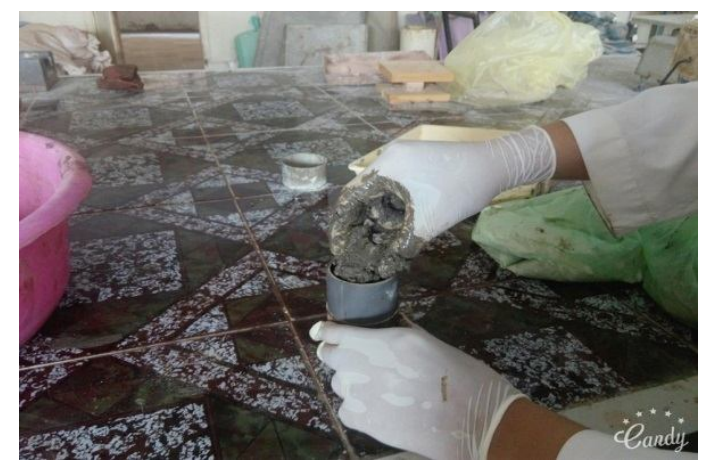




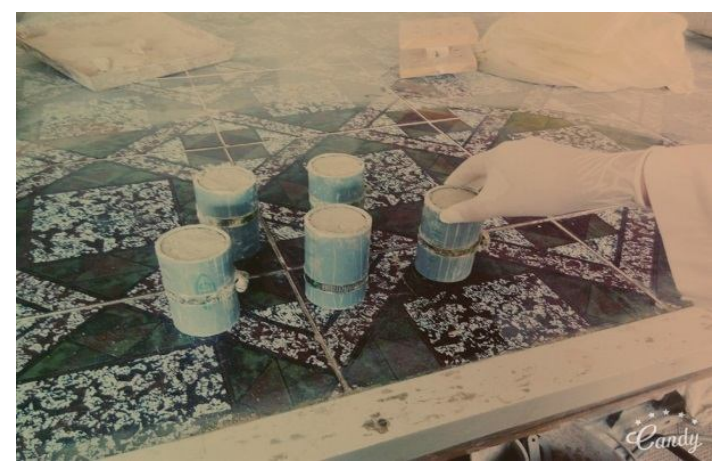

Photo (1): Soil samples during and after casting them in molds.

\subsubsection{Curing Time}

Curing times of $3,7,14$, and 28 days are used in this research. Three samples for each curing time are prepared in order to provide sufficient data for accurate interpolation of the test results.

\subsection{SMALL SCALE MODEL TESTS}

In addition to the unconfined compression testing, five small scale model tests are also performed to simulate the actual field improvement conditions, but in a scale suitable for laboratory testing. The variables are thickness of treated zone (h) and its extension (L) below the model footing as presented in Table (2). A steel tank having dimensions of $80 * 80 * 40 \mathrm{~cm}$ strengthened with four angles at its four sides is used in the small scale model tests. The tank is made watertight by welding all sides, and then painted with anti-rust paint. The model footing is an empty steel cuboid formed of welded edges stall lamina, having dimensions of $10 \mathrm{x}$ $10 \times 2 \mathrm{~cm}$. Dimensions of footing and tank are chosen to avoid the effect of tank side boundaries on the stressed soil behavior. The chosen width is more than 3 times the footing width from each side, and the tested soil depth of tank is $30 \mathrm{~cm}$ which is three times the footing width to achieve stress bulb condition.

The load is transferred into the footing steel cuboid using a steel loading arm. Two dial gauges are used to measure the settlement under different stresses over the test time period. The experimental model apparatus used in this study is shown in Figure (1).

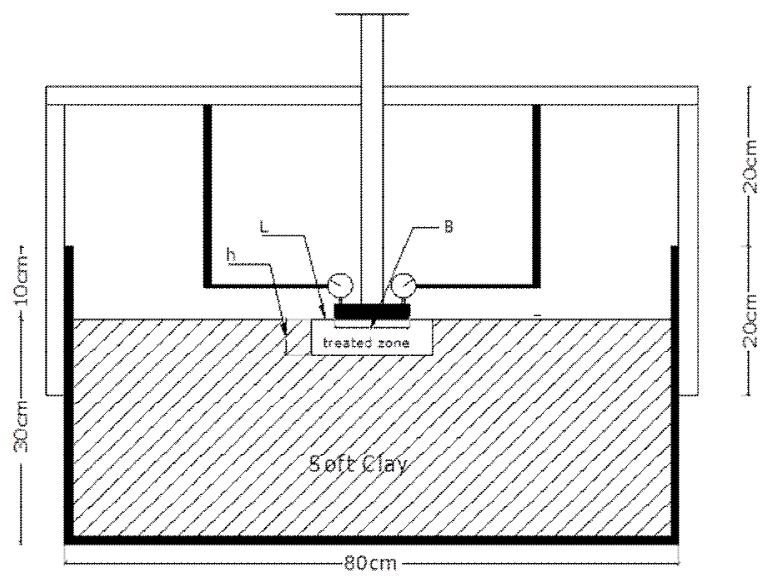

Figure (1-a): Diagrammatic Sketch of the Testing Tank.

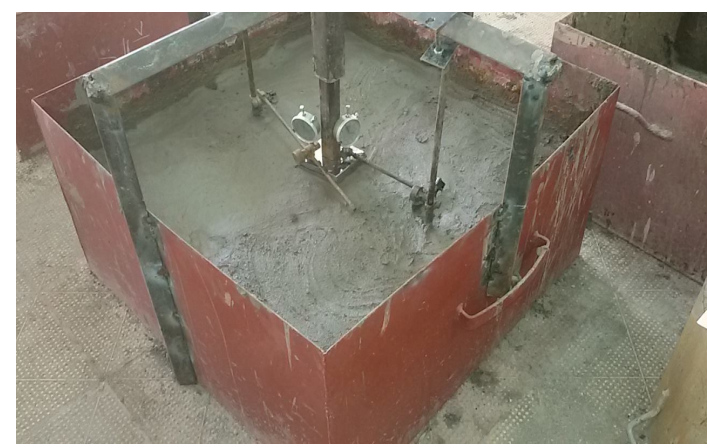

Figure (1-b): Photo of the Testing Tank.

The model footing and tank dimensions are:

Thickness of treated zone $=\mathrm{h}$;

Extension of treated zone $=\mathrm{L}$;

Depth of soft clay in the tank $=\mathrm{D}=30 \mathrm{~cm}$; and

Footing width $=\mathrm{B}=10 \mathrm{~cm}$.

\subsubsection{Soil Model Tests Preparation}

Soft clay soil is poured into the tank to fill about $30 \mathrm{~cm}$ of the tank full height, which is $40 \mathrm{~cm}$. The soil test surface is then carefully flattened by steel strip while causing no disturbance to the soft clay underneath.

\subsubsection{Stabilization Process}

To assure the highest possible quality of the lime stabilized soft clay zone underneath the test footing, a specially prepared mould having the same stabilized layer thickness is used. The intended 
stabilized soil is placed in the mould, then thoroughly mixed with the stabilizer, which could be cement powder, hydrated lime powder or both with the previously specified percentages. Mixing of the clay, lime and/or cement continued for a period of time to assure complete homogeneity of the resulting treated mix. The treated soil is left for 16 hours to slightly gain higher strength while maintaining its natural water content by wrapping the mould with damp cloth. After this treatment period which allows for the enhanced soil to be carefully transported into the soil tank and placed at its specific levelled location inside the testing tank.

\subsubsection{Stress-Settlement Tests}

Series of stress-settlement tests are performed on the treated and untreated soils. Just one single reference case is conducted over the natural soft soil without any kind of soil improvement or treatment. All other tests are done over improved soils with different degrees of improvements. The loading process starts immediately after placing the improved soil zone inside the testing tank, in which the stresses reached a maximum value of $30 \mathrm{kPa}$ including the footing weight.

The stresses are incrementally applied in 5 $\mathrm{kPa}$ increments over the whole testing period. For each loading increment $(5 \mathrm{kPa})$, settlement readings are recorded after 1, 2, 4, 8, 15, 30, $60 \mathrm{~min}, 2,4,24$ hours. Thus, the testing stress of $30 \mathrm{kPa}$ continued over 6 days with a $5 \mathrm{kPa}$ increment every day.

\section{PARAMETRIC STUDY}

Unconfined compressive strength tests are performed on the lime/cement treated soft clay specimens. Tests included varying the percent of either the lime, or cement, or both in preparing the specimens. Table (1) shows the natural water content of the soft clay along with the used stabilizer and its dosage. The added cement content ranges between 4.0 and $10 \%$ by dry weight. In addition to cement, lime contents ranges between 2.0 and $5.0 \%$ for different amounts of cement.

For the small scale models, five complete tests are performed exploring mainly the treated zone dimensions, and focusing on the treated zone thickness and width. Soft clay with no treatment is first performed to be a reference case for all the forthcoming tests. A treated zone thickness of 2.0 and $4.0 \mathrm{~cm}$ representing 20.0 and $40.0 \%$ of the footing width is placed just under the model footing, while keeping the treated width equal to the footing width. Two other tests are performed with an increased treated extended width of $20 \%$ of the footing width, as shown in Table (2).

Table (1): Dosage Rates of Stabilizers and Moisture Contents of Soil.

\begin{tabular}{|r|l|l|l|l|l|}
\hline $\begin{array}{r}\text { Soil } \\
\text { M.C. }\end{array}$ & Stabilizers & \multicolumn{4}{|c|}{$\begin{array}{c}\text { Stabilizer Dose Rate } \\
\text { (\% of Dry Weight) }\end{array}$} \\
\hline \multirow{5}{*}{$50 \%$} & $\begin{array}{l}\text { Portland } \\
\text { cement }\end{array}$ & $4 \%$ & $7 \%$ & $8 \%$ & $10 \%$ \\
\cline { 2 - 6 } & $\begin{array}{l}\text { Portland } \\
\text { cement }+ \\
\end{array}$ & $\begin{array}{l}4 \% \\
\text { hydrated } \\
\text { lime }\end{array}$ & $\begin{array}{l}7 \%+ \\
\%\end{array}$ & $\begin{array}{l}7 \%+ \\
2 \%\end{array}$ & $\begin{array}{l}10 \%+ \\
5 \%\end{array}$ \\
\hline
\end{tabular}

Table (2): Parameters of Small Model Tank Tests.

\begin{tabular}{|l|l|l|}
\hline \multicolumn{1}{|c|}{ Type of Test } & \multicolumn{1}{|c|}{$\begin{array}{c}\text { Constant } \\
\text { Parameters }\end{array}$} & $\begin{array}{l}\text { Variable } \\
\text { Parameters }\end{array}$ \\
\hline $\begin{array}{l}\text { Soft clay with no } \\
\text { treatment }\end{array}$ & $\begin{array}{l}\mathrm{D}=30 \mathrm{~cm}, \\
\mathrm{~B}=10 \mathrm{~cm}\end{array}$ & $\begin{array}{l}\mathrm{h}=0, \\
\mathrm{~L}=0\end{array}$ \\
\hline $\begin{array}{l}\text { Treated depth }=2 \mathrm{~cm}, \\
\text { No treated extended } \\
\text { width }\end{array}$ & $\begin{array}{l}\mathrm{D}=30 \mathrm{~cm}, \\
\mathrm{~B}=10 \mathrm{~cm}\end{array}$ & $\begin{array}{l}\mathrm{h}=2 \mathrm{~cm}, \\
\mathrm{~L}=0\end{array}$ \\
\hline $\begin{array}{l}\text { Treated depth }=2 \mathrm{~cm}, \\
\text { Treated extended } \\
\text { width }=2 \mathrm{~cm}\end{array}$ & $\begin{array}{l}\mathrm{D}=30 \mathrm{~cm}, \\
\mathrm{~B}=10 \mathrm{~cm}\end{array}$ & $\begin{array}{l}\mathrm{h}=2 \mathrm{~cm}, \\
\mathrm{~L}=2 \mathrm{~cm}\end{array}$ \\
\hline $\begin{array}{l}\text { Treated depth }=4 \mathrm{~cm}, \\
\text { No treated extended } \\
\text { width }\end{array}$ & $\begin{array}{l}\mathrm{D}=30 \mathrm{~cm}, \\
\mathrm{~B}=10 \mathrm{~cm}\end{array}$ & $\begin{array}{l}\mathrm{h}=4 \mathrm{~cm}, \\
\mathrm{~L}=0\end{array}$ \\
\hline $\begin{array}{l}\text { Treated depth }=4 \mathrm{~cm}, \\
\text { Treated extended } \\
\text { width }=2 \mathrm{~cm}\end{array}$ & $\begin{array}{l}\mathrm{D}=30 \mathrm{~cm}, \\
\mathrm{~B}=10 \mathrm{~cm}\end{array}$ & $\begin{array}{l}\mathrm{h}=4 \mathrm{~cm}, \\
\mathrm{~L}=2 \mathrm{~cm}\end{array}$ \\
\hline
\end{tabular}

\section{UNCONFINED COMPRESSION STRENGTH TEST RESULTS}

\subsection{Effect of Cement Content on Soft Clay Soil}

Only lime treated specimens are performed at the beginning of this study, but gave low UCS values when compared with specimens treated with cement only or cement with lime. The presence of cement, even with low dosage, initiates the Pozzolanic reaction which allows for the lime to be effective strength additive.

It was also found that typical unconfined compressive strength tests could not be performed on soft clay specimens due to the soft consistency which will not allow the specimens to stand the testing process. However, pure cement treatment resulted in considerable strength gain increasing the UCS values 
from the typical soft clay values of about $25 \mathrm{kPa}$ or less to about $298 \mathrm{kPa}$ when adding $4.0 \%$ cement only. Increasing the cement content from $4.0 \%$ up to $7.0 \%$ resulted in even more increase in the UCS values to reach $497 \mathrm{kPa}$, with net increase of about two thirds over the initially treated ones. A moderate increase in the UCS values continued when increasing the cement content to $8 \%$ (reached 549 $\mathrm{kPa}$ ) and $10 \%$ (reached $680 \mathrm{kPa}$ ), all tested after 28 days, as shown in Figure (2).

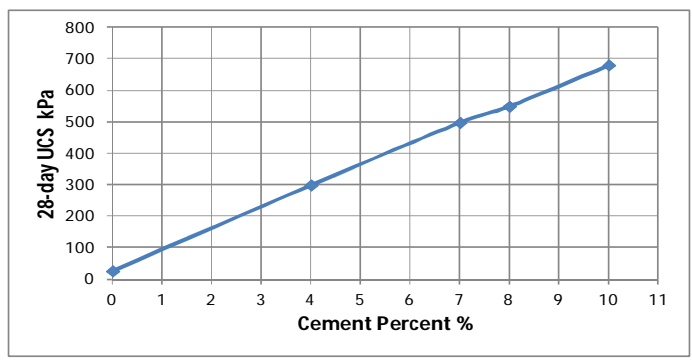

Figure (2): Effect of Increasing the Cement Percent on the UCS after 28 Days.

\subsection{Effect of Curing Time on UCS for Cement Treated Soil}

Figure (3) shows the relation between UCS and curing time when using cement percentage of 4\%. Results indicated that curing time has a significant effect on the strength of the cementtreated samples. The strength of the tested specimens is plotted for curing times of 3, 7, 14, and 28 days. A significant increase in the UCS values is noticed for longer curing times. A consistent increase in strength of $51.7 \%, 197.2 \%, 270.64 \%$ over the 3 day UCS value for curing times of 7,14 , and 28 respectively. However, the rate of strength gain that took place before 14 days is higher than that took place after 14 days. Thus, the effect of curing time is very crucial for the soft clay improvement. Moreover, it is likely that the strength gain will continue after 28 days, but with slightly reduced rate.

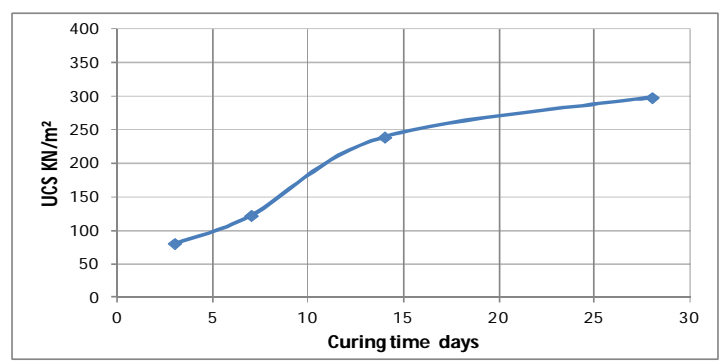

Figure (3): Effect of Curing Time on UCS for $4 \%$ Cement Treated Soft Clay.

\subsection{Effect of Lime on Soil Treated with Cement}

Mixing soft clay with cement and lime resulted in continuous strength increase over time. Adding cement alone resulted in a significant increase in UCS strength from the time of mixing up to 14 days, followed by a slightly decreased rate of strength gain. However, this is not the case when adding lime. Cement-lime treatment of soft clay is a continuous improvement process due to the chemical reactions that occur between the lime, cement, and clay particles. These chemical reactions occur in two phases, with both immediate and long-term benefits.

The first phase of the chemical reaction involves immediate changes in soil texture and soil properties caused by cation exchange. The free calcium of the lime exchanges with the adsorbed cations of the clay minerals, resulting in reduction in size of the diffused water layer surrounding the clay particles. This reduction in the diffused water layer allows the clay particles to come into closer contact with one another, causing flocculation/agglomeration of the clay particles, which transforms the clay into a more silt-like or sand-like material. Overall, the flocculation and agglomeration phase of lime stabilization results in a soil that is more readily mixable, workable, and ultimately, compactable, as stated by Geiman (2005). According to Eades and Grim (1960), practically all fine-grained soils undergo this rapid cation exchange and flocculation/ agglomeration reactions when treated with lime in the presence of water.

The second phase of the chemical reaction involves pozzolanic reactions within the lime-soil mixture, resulting in strength gain over time. When lime is combined with a clay soil, $\mathrm{pH}$ of the pore water increases. When the $\mathrm{pH}$ reaches 12.4 , the silica and alumina from the clay become soluble and are released from the clay mineral. In turn, the released silica and alumina react with the calcium from the lime to form cement, which strengthens in a gradual process that continues for several years, Eades and Grim, (1960). As long as there is sufficient calcium from the lime to combine with the soluble silica and alumina, the pozzolanic reaction will continue as long as the $\mathrm{pH}$ remains high enough to maintain the solubility of the silica and alumina (Little, 1995). Strength gain also largely depends on the amount of silica and alumina available from the clay itself. On the other hand, $\mathrm{pH}$ with ultra-higher values may result in poisonous effect on the groundwater. 
In addition to pozzolanic reactions, carbonation can also lead to long-term strength increases for soils stabilized with lime. Carbonation occurs when lime reacts with carbon dioxide from the atmosphere to produce a relatively insoluble calcium carbonate. This can be advantageous since after mixing, the slow process of carbonation and formation of cementitious products can lead to longterm strength increases (Arman and Munfakh, 1970). However, prior to mixing, exposure of lime to air should be avoided through proper handling methods and expedited construction procedures in order to avoid premature carbonation of the lime (Chou, 1987).

Figure (4) shows that adding hydrated lime to the cement mixed soft clay resulted in higher UCS values. Tests are conducted on specimens treated with $4 \%$ cement only and other specimens treated with $4 \%$ cement plus $4 \%$ lime. It is noticed that the UCS values of cement-lime treated soft clay is noticeably higher than those mixed with cement only. Considering the UCS after 28 days as a reference value, about $70 \%$ strength gain could be achieved in this case. Moreover, in the presence of lime, the rate of strength gain is much higher than the soft clay cement treated samples. After 14 days, the strength gain reached about $42 \%$ for lime and cement treated samples and reached about $24 \%$ for cement only treated samples. This is a great advantage for using the cheaper hydrated lime as a soft soil stabilizer, while obtaining higher strength UCS values.

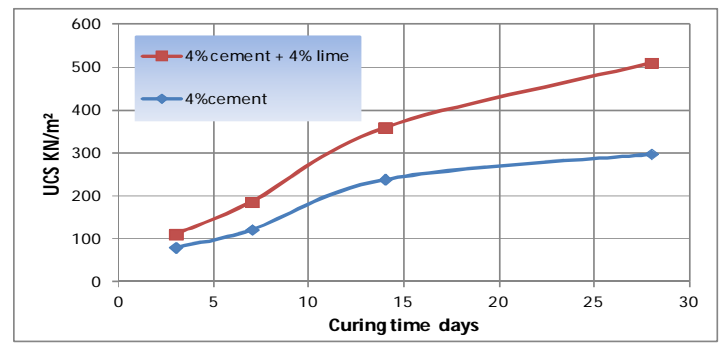

Figure (4): Effect of Lime on UCS of $4 \%$ Cement Treated Clay.

Increasing the percentage of cement content up to $7 \%$ although resulted in higher strength than the $4 \%$ UCS values, but the effect of hydrated lime becomes less pronounced even with $2 \%$ and $5 \%$ added lime cases. Figure (5) showed relation between UCS of treated soft clay specimens and curing time when using constant percentage of cement equal to
$7 \%$ and various percentages of lime. Slight increases of about $10 \%$ and $18 \%$ are noticed when adding lime with $2 \%$ and $5 \%$ respectively to the $7 \%$ cement treated specimens.

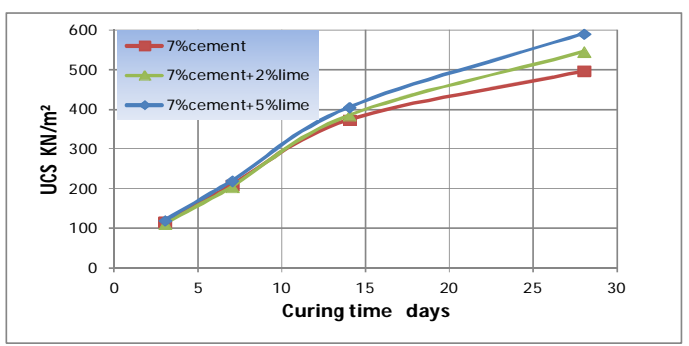

Figure (5): Effect of Adding 2\% and 5\% Lime on UCS of 7\% Cement Treated Soft Clay.

The soft clay treatment behavior noticed in Figure (5) is more pronounced in Figure (6) in which the cement content increased to $10 \%$. Adding 5\% lime resulted in about $5 \%$ increase in the UCS of $10 \%$ cement treated samples, which could be negligible when compared with clay specimens treated with lower percentages of cement. This may be attributed to the fact that increasing the cement content in the cement treated soft clay samples resulted in somewhat highly initial hardened clay hindering the effect of lime reaction. On the other hand, lower cement contents allows for the lime to react with the slightly lower strength cement-clay mix giving more clear view of the lime effect.

It should be noted that the soil improvement process is not intended to change the soft clay into higher strength material (very stiff or hard clay) but rather allow for the treated site soil to increase its bearing capacity and reduce the settlements under relatively low structure loads. Deep layers of soft clay do not allow for higher structure loads because of the limited depth of the improved soils when compared with the untreated soils.

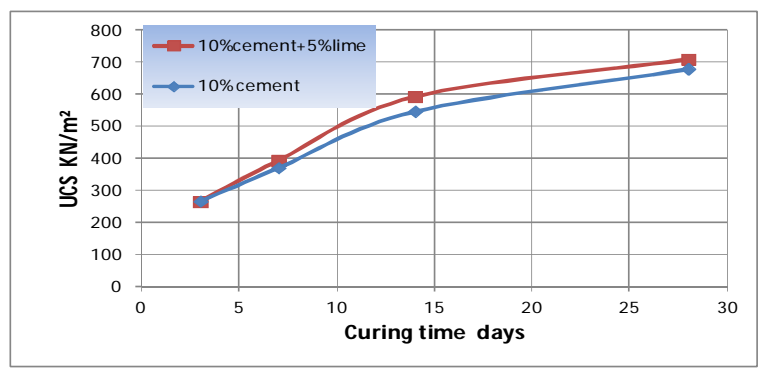

Figure (6): Effect of Lime on UCS of 10\% Cement Treated Clay. 


\section{SMALL SCALE MODEL RESULTS}

In addition to the UCS tests conducted on cement/lime treated soft clay, a group of small scale model tests are performed on the lab to model the field soil improvement cases. The improvement thickness and extension below the footing model are the main focus of these experiments. Field improvement techniques include cultivation of specific predefined thickness of the soft clay improved zone, just below the foundations or the highway base layer.

A reference case in which no improvement is conducted first and is termed no-improvement case. In this case, a low stress of $30 \mathrm{kPa}$ resulted in a total settlement of $10.34 \mathrm{~mm}$, which is about $10.30 \%$ of the footing width, a clearly large total settlement.

\subsection{Effect Treated Zone Thickness}

In addition to the reference case, two treated soil thicknesses, just under the footing model, are studied. The studied thicknesses are $20 \%$ and $40 \%$ of the footing width. Figure (7) shows the relation between stress and settlement for different values of treated thickness (h). Improving a layer thickness of $20 \%$ the footing width (B) resulted in about $31 \%$ reduction in the measured total settlements. Moreover, increasing the improved soil layer thickness to reach $40 \%$ of the footing width resulted in about $41.0 \%$ reduction in the measured total settlement. It should be noted that the improved zone width was chosen to be exactly equal to the footing width without any projection. The effect of improved soil extension will be studied separately later on.

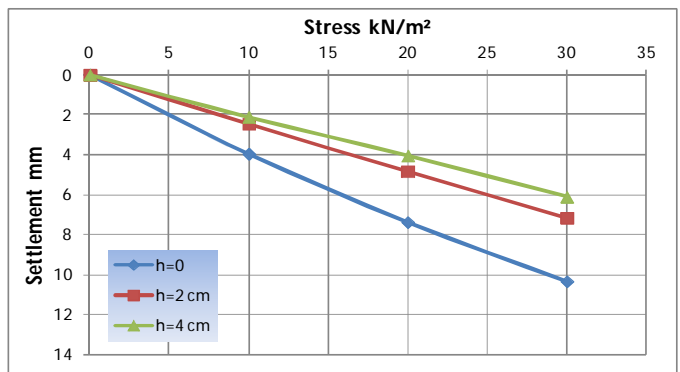

Figure (7): Effect of Treated Layer Thickness (h) on Settlement.

\subsection{Effect of Treated Zone Extension}

Figures (8) presented the effect treated zone extension (L) on settlement. At a treated thickness (h) equal to $2 \mathrm{~cm}$, results showed that the measured settlements decreased from $7.15 \mathrm{~cm}$ to $6.65 \mathrm{~cm}$ which is about $7 \%$ by increasing the treated extension width (L) from 0 to $2 \mathrm{~cm}$ from each side. At a treated thickness (h) equal to $4 \mathrm{~cm}$, the settlement decreased from $6.1 \mathrm{~cm}$ to $5.5 \mathrm{~cm}$ which is about $10 \%$ when the treated extension width (L) is equal to $2 \mathrm{~cm}$ from each side.

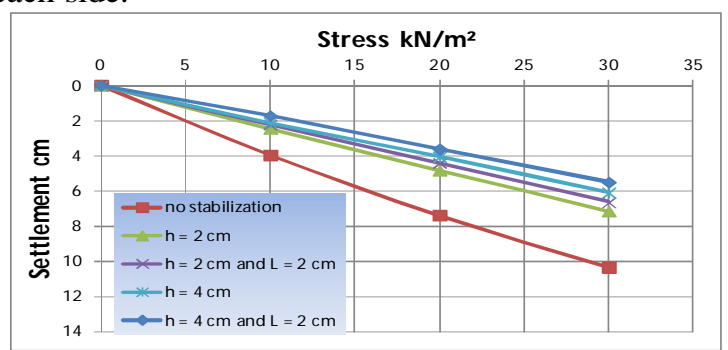

Figure (8): Effect of Extension of Treated Zone (L) on Settlement.

\subsection{Effect of Time on Settlement}

Figure (9) presents relationship between settlement and time at stress $=10 \mathrm{kN} / \mathrm{m}^{2}$ for the case of no stabilization and case of treatment thickness is equal to $20 \%$ of the footing width. Results showed that most of the settlement took place in first 100 minutes or so for both cases and the rate of settlement increase consistently decreased over time to stop completely after $24 \mathrm{hr}$ (1440 min).

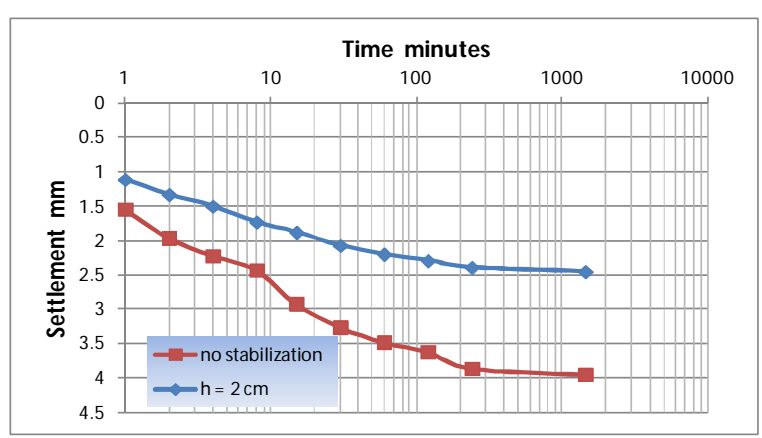

Figure (9): Effect of Time on Settlement.

\section{CONCLUSION}

1- Hydrated lime and Portland cement are effective in increasing UCS of soft clay soils. For high dosage of cement (from $7 \%$ to $10 \%$ ), the effectiveness of lime is low. The 28 day UCS of $10 \%$ Portland cement $+5 \%$ hydrated lime is 710 $\mathrm{kN} / \mathrm{m}^{2}$ and for $10 \%$ Portland cement only is 680 $\mathrm{kN} / \mathrm{m}^{2}$ with variation not exceeding $4.2 \%$.

2- For low dosage rate of cement (4\%) the effectiveness of lime is significant. The 28 day UCS of $4 \%$ Portland cement $+4 \%$ hydrated lime is $510 \mathrm{kN} / \mathrm{m}^{2}$ and for $4 \%$ Portland cement 
only is $298 \mathrm{kN} / \mathrm{m}^{2}$ with about $70 \%$ strength gain.

3- Curing time has a noticeable impact on the strength of the cement-treated samples and cement-lime mixture treated samples. The strength of the specimens tested at a curing time of 3 days achieved 20 to $40 \%$ of the 28-day UCS, specimens tested at a curing time of 7 days achieved 40 to $55 \%$ of the 28-day UCS, and reached 70 to $85 \%$ of the 28 -day UCS at 14 days.

4- A soft clay improvement-scheme containing a mixture of $4 \%$ cement $+4 \%$ lime is recommended to improve the soft clay soil strength and deformation characteristics to be able to safely support low rise buildings of one and two story buildings.

5- Small scale model tests showed that using a layer of cement-lime treated soil thickness (h) of $20 \%$ the footing width reduced the measured total settlements by about $30 \%$.

6- The reduction rate of settlement decreased when using larger values of treated depth. It is found that the total settlement decreased by about additional $15 \%$ when increasing the treated thickness (h) from 20 to $40 \%$ of the footing width.

7- A moderate decrease in the total settlements ranging from $7 \%$ to $10 \%$ is noticed when increasing the treated soil zone projection by $20 \%$ for both treatment depths of 20 and $40 \%$ respectively.

\section{REFERNCES}

(1) Arman, A., and Munfakh, G.A., (1970), "Stabilization of Organic Soils with Lime", Engineering Research Bulletin, No. 103, Division of Engineering Research, Louisiana State University, Baton Rouge.

(2) Chou, L., (1987), "Lime Stabilization: Reactions, Properties, Design, and Construction", State of the Art Report 5, Transportation Research Board, Washington, DC.

(3) Dhakal, S.K., (2009), "Stabilization of Very Weak Subgrade Soil with Cementitious Stabilizers", M.Sc, Department of Civil Engineering, Faculty of the Louisiana State University and Agricultural and Mechanical College, Louisiana, USA.

(4) Eades, J.L., and Grim, R.E., (1960), "Reaction of Hydrated Lime with Pure Clay Minerals in
Soil Stabilization", Bulletin 262, Highway Research Board, Washington, DC.

(5) Geiman, C.M., (2005), "Stabilization of Soft Clay Subgrades in Virginia Phase I Laboratory Study", M.Sc. Thesis, Department of Civil Engineering, Faculty of Virginia Polytechnic Institute and State University, Virginia, USA.

(6) Ismaiel, H.A., (2006), "Treatment and Improvement of the Geotechnical Properties of Different Soft Fine-Grained Soils Using Chemical Stabilization", Mathematisch-Naturwissenschaftlich-

Technischen Fakultät der Martin-LutherUniversität Halle-Wittenberg eingereicht.

(7) Little, D.N., (1995), "Handbook for Stabilization of Pavement Subgrades and Base Courses with Lime", Kendall/Hunt, Iowa.

(8) Muhamed, A., and Wanatowski, D., (2013), "Effect of Lime Stabilization on the Strength and Microstructure of Clay", IOSR Journal of Mechanical and Civil Engineering (IOSR-JMCE), Vol. 6, Issue. 3, PP. 87-94.

(9) Nordin, N.D., (2010), "The Potential of Cement Stabilization in Soft Soil", M.Sc. Thesis, Department of Civil Engineering, University Malaysia Pahang, Malaysia.

(10) Portelinha, F.H., Lima, D.C., Fontes, M.P., and Carvalho, C.A., (2012), "Modification of a Lateritic Soil with Lime and Cement: An Economical Alternative for Flexible Pavement Layers", Soils and Rocks, São Paulo, Vol.35, No.1, pp.51-63.

(11) Rafalko, S., (2006), "Rapid Soil Stabilization of Soft Clay Soils for Contingency Airfields", M.Sc. Thesis, Department of Civil Engineering, Faculty of Virginia Polytechnic Institute and State University, Virginia, USA.

(12) Yunus, N.Z., Wanatowski, D., and Stace, L.R., (2012), "Effectiveness of Chloride Salts on the Behavior of Lime-Stabilized Organic Clay", Int. J. of GEOMATE, Vol. 3, No. 2, pp. 407-412.

(13) Zukri, A., (2013), "Pekan Soft Clay Treated With Hydrated Lime as a Method of Soil Stabilizer", Malaysian Technical Universities Conference on Engineering \& Technology, MUCET 2012, Part 3, Civil and Chemical Engineering, pp.37-41. 